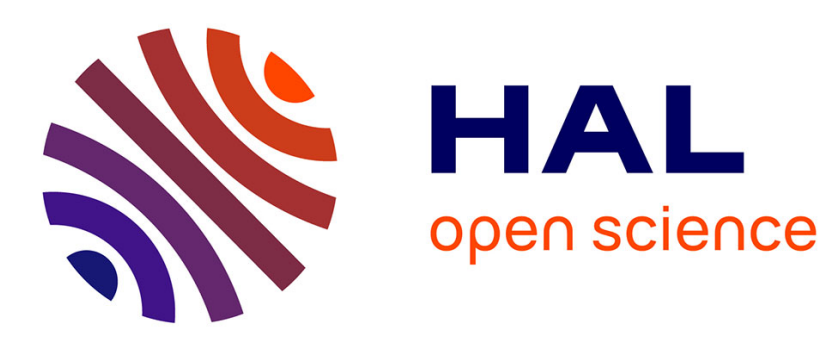

\title{
Quest for biomarkers of the lean-to-fat ratio by Proteomics in beef production
}

\author{
Muriel Bonnet, Nicolas Kaspric, Brigitte B. Picard
}

\section{To cite this version:}

Muriel Bonnet, Nicolas Kaspric, Brigitte B. Picard. Quest for biomarkers of the lean-to-fat ratio by Proteomics in beef production. 3. Meeting of Working Groups 1, 2, 3 of COST Action FA1002, Apr 2013, Kosice, Slovakia. 303 p. hal-02744639

\section{HAL Id: hal-02744639 \\ https://hal.inrae.fr/hal-02744639}

Submitted on 3 Jun 2020

HAL is a multi-disciplinary open access archive for the deposit and dissemination of scientific research documents, whether they are published or not. The documents may come from teaching and research institutions in France or abroad, or from public or private research centers.
L'archive ouverte pluridisciplinaire HAL, est destinée au dépôt et à la diffusion de documents scientifiques de niveau recherche, publiés ou non, émanant des établissements d'enseignement et de recherche français ou étrangers, des laboratoires publics ou privés. 


\section{Form enimel proteomias 2013}

Proceedings of the $4^{\text {th }}$ Management Committee Meeting and $3^{\text {rd }}$ Meeting of Working Groups 1, $2 \& 3$ of COST Action FA 1002 Košice, Slovakia - 25-26 April 2013

edited by:

André de Almeida David Eckersall -

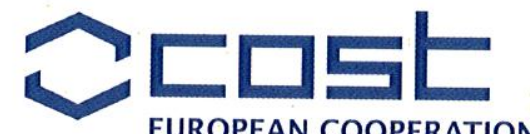
EUROPEAN COOPERATION IN SCIENCE AND TECHNOLOGY

Elena Bencurova Saskia Dolinska Patrik Mlynarcik Miroslava Vincova Mangesh Bhide

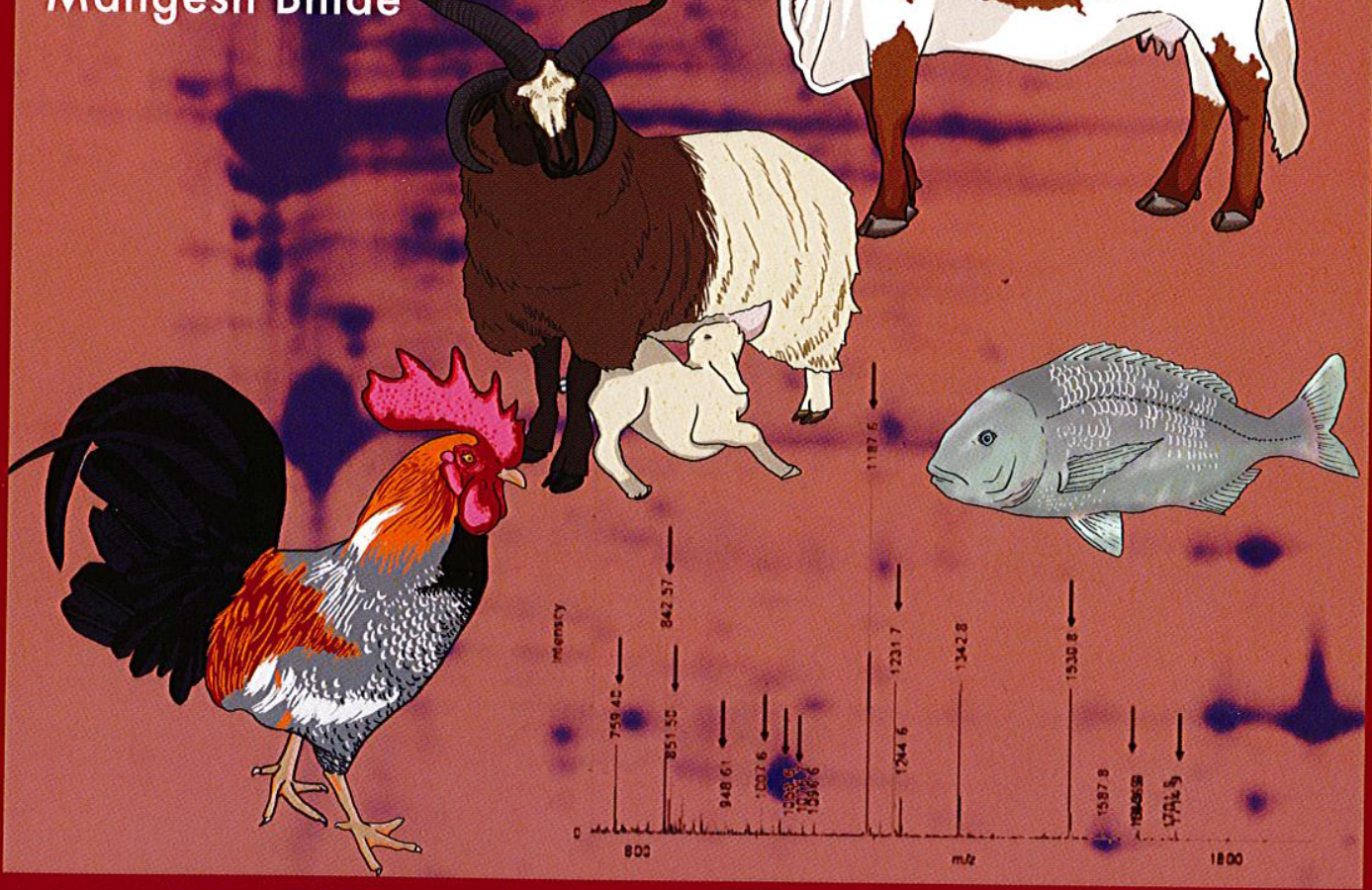




\section{Quest for biomarkers of the lean-to-fat ratio by proteomics in beef production}

Muriel Bonnet ${ }^{l, 2}$, Nicolas Kaspric ${ }^{l, 2}$, Brigitte Picard ${ }^{l, 2}$

${ }^{1}$ INRA, UMR1213 Herbivores, 63122 Saint-Genès-Champanelle, France,

muriel.bonnet@clermont.inra.fi

${ }^{2}$ VetAgro Sup, Élevage et production des ruminants, 63370 Lempdes, France

Producing meat animals with adequate muscular and adipose masses (i.e. lean-to-fat ratio) is an economic challenge for the beef industry. In cattle, conformation (muscle mass) and fatness (adipose tissue mass) are evaluated using the European Union beef carcass classification system (EUROP) scale. The EUROP scale determines the price/kg of carcasses. The lean-to-fat ratio is the result of a dynamic balance between the number and size of muscular and adipose cells, respectively (Bonnet et al., 2010). Identifying proteins that contribute to the increase in the number and volume of adipose and muscular cells has implication for the proposition of biomarkers of growth potential and/or of carcass composition.

The total number of muscle fibres is set by the end of the second trimester of gestation (Picard $e t$ al., 2002). Conversely, the number of adipocytes is set by birth or by early adulthood, depending on the anatomical location of the adipose tissue (Vernon, 1986). Thus, we hyppthesized that high through mo me a high increase in the number and the size of moscular and adipose cells.

We combined measurements of chemical composition, cellularity, histology, enzyme activities gene expression and proteomics to describe the ontogeny of perirenal AT and Semitendinosus muscle in bovine at 60,110, 180, 210 and 260 days post conception (dpc) in Blond d'Aquitaine ( $\mathrm{n}=3$ per age) and Charolais ( $\mathrm{n}=5$ per age) breeds. These breeds were chosen for their differences in lean-to-fat ratio in the post-natal life.

Between 110 and $260 \mathrm{dpc}$ (38 and 90\% of gestation length, respectively), the increase in the weight of perirenal AT resulted from an increase in the volume and mainly in the number of adipocytes (Taga et al. 2011). The increases in adipocyte volume and number were accompanied by changes in the abundance of 128 proteins among the 143 proteins identified and common to the four last fetal ages studied (Taga et al 2012). Among the identified proteins, some of them identifed to hyperpasia of adposeprecuson, by contoling cell cycle progession, apoptosis and/or by delaying adipocyte differentiation. The age of $180 \mathrm{dpc}$ seems to be a pivotal age for the transition between proliferation and differentiation of adipocyte progenitors. An increase in the abundance of many proteins involved in differentiation and in the increase in adipocyte volume was observed from $180 \mathrm{dpc}$.

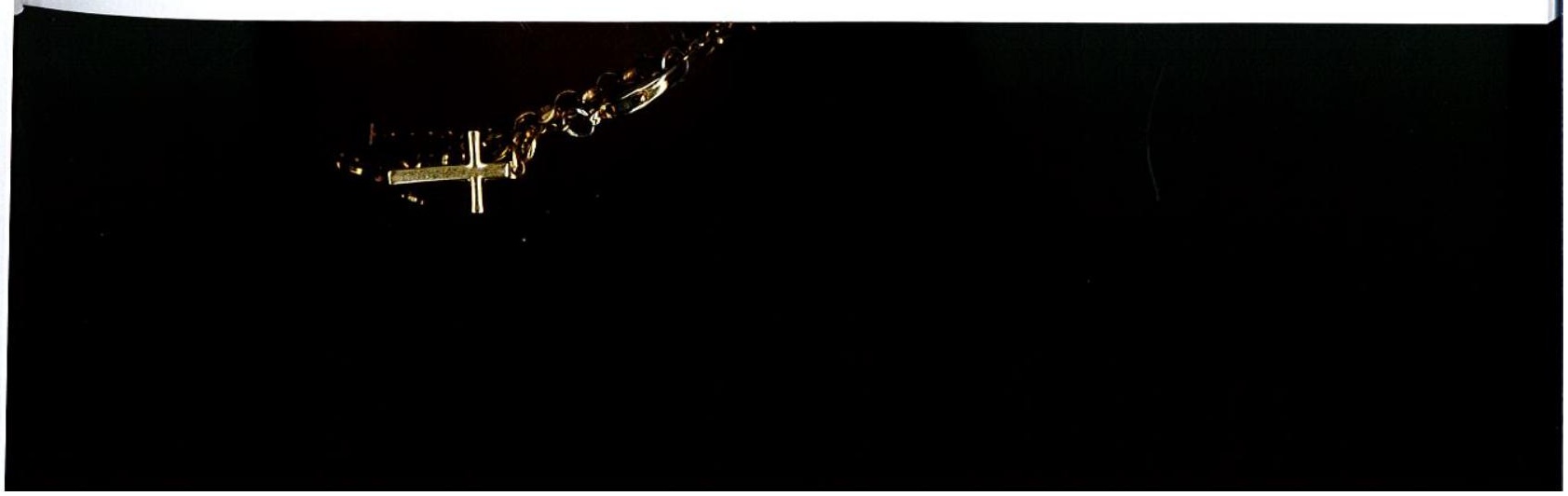


The fetal growth of semitendinosus muscle was accompanied by changes in the abundance of 245 proteins. We revealed high abundance of proteins involved in apoptosis at 60 and $110 \mathrm{dpc}$, suggesting that the proliferation - apoptosis balance may play a role in the determination of the total number of fibers (Chaze et al., 2008). The age of $180 \mathrm{dpc}$ corresponds to a reduction in cell proliferation and a transition between the formation of myofibres and their maturation. Indeed, the abundance of stathmin, which has an important role in cell cycle regulation, decreased from $180 \mathrm{dpc}$ onwards. Septin proteins (septin 2 and 11 isoforms) involved in cytoskeletal organisation, scaffolding and cell division plane had a stable expression up to 180 $\mathrm{dpc}$, consistent with intense cell division until this stage, and declined thereafter. Annexin A1, which has an anti proliferative function via the activation of ERK pathways, showed increased abundance from $180 \mathrm{dpc}$ onwards. Increased maturation of fibers from 180 to $260 \mathrm{dpc}$ is reflected by significant changes in the profiles of protein isoforms belonging to metabolic and contractile pathways (Chaze et al, 2009).

The cellular and molecular features of AT and muscle during ontogenesis provide potentia hallmarks of adipose and muscular cells hyperplasia or hypertrophy. Among these protein we hypothesize there are 'master' proteins, thus a current integrative bioinformatic analysis we hypothesize there are 'master' proteins, thus a current integrative bioinformatic analysis
of adipose and muscular data aims to identify them. Then, the relationship between the abundance of these proteins and data from carcass composition will be studied in tissues from meat producing cattle differing by their rearing conditions or by their genotypes.

\section{References}

Bonnet, M., Cassar-Malek, I., Chilliard, Y. and Picard, B., 2010. Ontogenesis of muscle and adipose tissues and their interactions in ruminants and other species. Animal 4: 1093-1109.

Chaze, T., Meunier, B., Chambon, C., Jurie, C. and Picard, B., 2008. In vivo proteome dynamics during ensty bovine myogenesis. Proteomics 8: 4236-4248.

Chaze, T., Meunier, B., Chambon, C. Jurie, C. and Picard, B. 2009. Proteome dynamics during controtile metabolic differentiation of bovine foetal muscle. Animal 3: 980-1000.

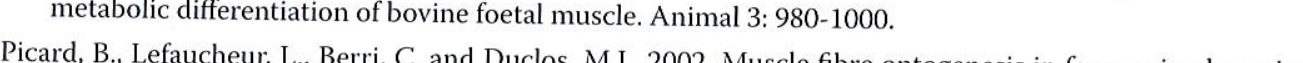
Reproduction, Nutrition, Development 42: 415-431.

Taga, H., Bonnet, M., Picard, B., Zingaretti, M.C., Cassar-Malek, I., Cinti, S. and Chilliard, Y., 2011. Adipocyte metabolism and cellularity are related to differences in adipose tissue maturity between Holstein and Charolais or Blond d'Aquitaine fetuses. Journal of Animal Science 89: 711-721.

Taga, H., Chilliard, Y., Meunier, B., Chambon, C., Picard, B., Zingaretti, M.C., Cinti, S. and Bonnet, M., 2012. Cellular and molecular large-scale features of fetal adipose tissue: is bovine perirenal adipose tissue brown? Journal of Cellular Physiology 227 1688-1700

Vernon, R.G., 1986. The growth and metabolism of Adipocytes. In: P.J. Buttery, D.B. Lindsay and N.B. Haynes (Eds.), Control and Manipulation of Animal Growth. Butterworths, London., pp. 67-83. 